\title{
The power of narrative images
}

Citation for published version (APA):

Farace, S. (2019). The power of narrative images: a visual semiotic analysis of consumer and brand messages in social media. [Doctoral Thesis, Maastricht University]. ProefschriftMaken Maastricht. https://doi.org/10.26481/dis.20190618sf

Document status and date:

Published: 01/01/2019

DOI:

10.26481/dis.20190618sf

Document Version:

Publisher's PDF, also known as Version of record

\section{Please check the document version of this publication:}

- A submitted manuscript is the version of the article upon submission and before peer-review. There can be important differences between the submitted version and the official published version of record.

People interested in the research are advised to contact the author for the final version of the publication, or visit the DOI to the publisher's website.

- The final author version and the galley proof are versions of the publication after peer review.

- The final published version features the final layout of the paper including the volume, issue and page numbers.

Link to publication

\footnotetext{
General rights rights.

- You may freely distribute the URL identifying the publication in the public portal. please follow below link for the End User Agreement:

www.umlib.nl/taverne-license

Take down policy

If you believe that this document breaches copyright please contact us at:

repository@maastrichtuniversity.nl

providing details and we will investigate your claim.
}

Copyright and moral rights for the publications made accessible in the public portal are retained by the authors and/or other copyright owners and it is a condition of accessing publications that users recognise and abide by the legal requirements associated with these

- Users may download and print one copy of any publication from the public portal for the purpose of private study or research.

- You may not further distribute the material or use it for any profit-making activity or commercial gain

If the publication is distributed under the terms of Article $25 \mathrm{fa}$ of the Dutch Copyright Act, indicated by the "Taverne" license above, 
Summary 
The present dissertation provides an in-depth discussion of visual semiotic theory, as applied to the marketing and consumer behavior fields, using experimental methods, content analysis of images, and text mining. In three chapters, I have shown that by using visual semiotics as an enabling framework, we can obtain relevant theoretical and practical insights regarding the power of narrative images in consumer and brand messages shared on social media.

Chapter 2 shows how consumer selfies are powerful tools for companies to spread a message about a brand or product. This Chapter contributes to the marketing literature by challenging the belief that photos merely serve as memorable representations of consumers' personal life stories. In considering visual aspects such as the narrative perspective, content, and photographic style, we show that consumer photos function as messages that trigger viewer response in terms of eWOM.

Chapter 3 shifts to the context of company-generated content (i.e., ads) shared on social media platforms. Online channels such as Twitter and Facebook have become crucial to engage consumers with brand-related narratives. However, content managers struggle in composing narrative messages that are engaging consumers. In using experiments and content analysis of social media brand posts, this chapter sheds light on compositional aspects that can strengthen the persuasiveness of a social media post. Specifically, we investigate how the alignment (visual patterns) of visual objects affects consumer evaluation. Chapter 3 thus contributes to research on social media marketing by offering a more nuanced understanding of social media brand messages composition and their implication for consumer evaluations and sharing.

Chapter 4 provides insights into the role of storytelling in social media conversations. This Chapter emphasizes the power of narrative images in conveying a message to consumers. In using real posts across two social media platforms, i.e., Twitter and Facebook, we are able to show that narrative images are shared more than non-narrative ones. However, there are visual aspects that may negatively affect the relationship between narrative images and consumer sharing. For example, the actors portrayed in the narrative, and textual features, i.e., text within the image and caption complexity, can harm consumer sharing of brand-related narratives. Chapter 4 thus contributes to research on social media marketing and storytelling by providing a novel understanding of brand-related narratives for social media conversations. 